(6)

\section{OPEN ACCESS}

'Emergency Surgery, University of Bologna, Bologna, Italy ${ }^{2}$ Pathological Anatomy, University of Bologna, Bologna, Italy

\section{Correspondence to}

Professor Valeria Tonini, valeria.tonini@unibo.it

Accepted 2 June 2018

\title{
Giant abdominal metastasis from cardiac liposarcoma
}

\author{
Valeria Tonini, ${ }^{1}$ Guglielmo Gozzi, ${ }^{1}$ Maria Giulia Pirini, ${ }^{2}$ Maurizio Cervellera ${ }^{1}$
}

\section{DESCRIPTION}

The patient was a 58 -year-old man. His history began 6 years before the admission to our hospital because of a syncopal episode. MRI showed a $2 \mathrm{~cm}$ lesion at the confluence of the left pulmonary veins. It was surgically removed and the histopathological diagnosis was of 'pleomorphic liposarcoma'. The postoperative course was regular.

Since the patient lived in a rural area, he was not treated in a high-volume reference centre for sarcoma and follow-up was not managed by a dedicated multidisciplinary team. Three years later, for the onset of an intestinal occlusion, he underwent emergency laparotomy. An ileo-ileal invagination due to a little ileal lesion was treated with a $30 \mathrm{~cm}$ intestinal resection. The histopathological response was again of liposarcoma. Chemotherapy was not performed.

One year later, a thoracoabdominal CT scan showed a heart recurrence and an enormous abdominal mass involving many ileal loops with intestinal subocclusion. The patient was evaluated

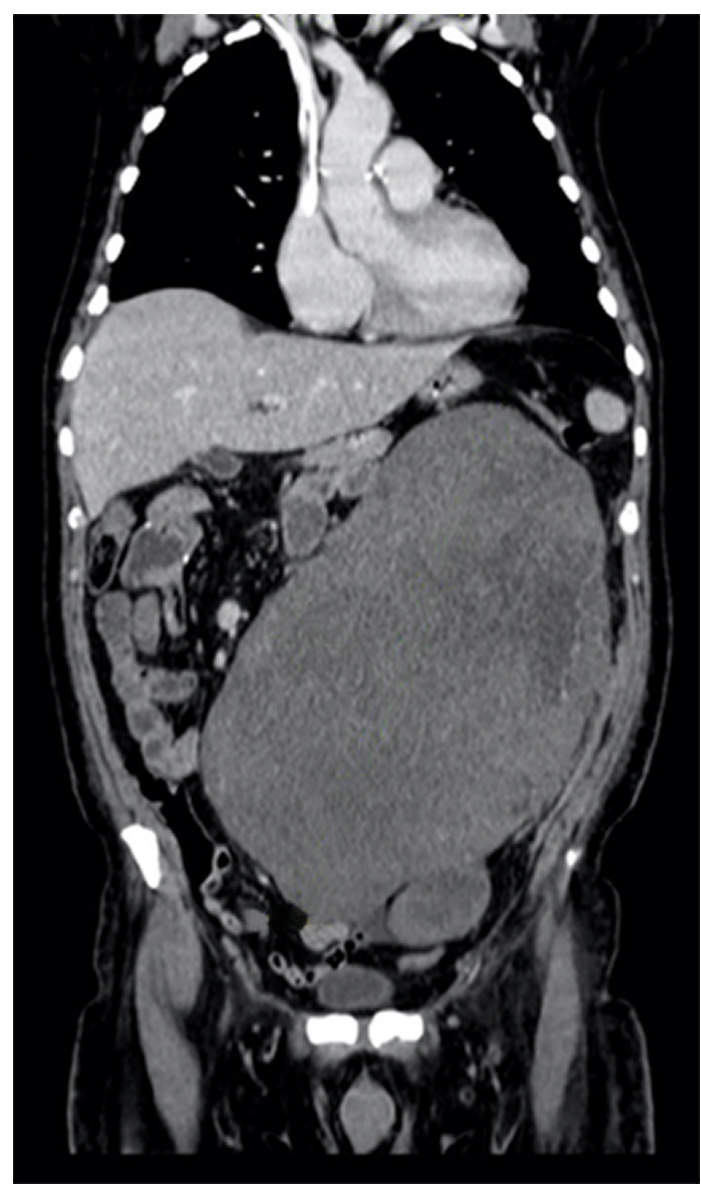

Figure 1 CT scan showing both abdominal and cardiac recurrences.

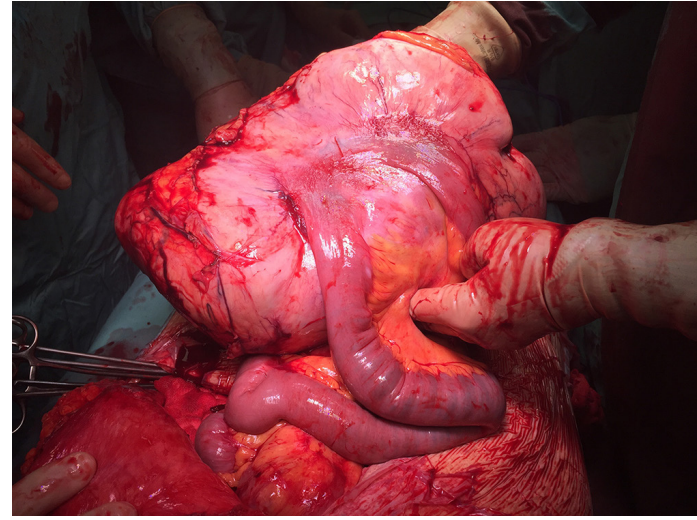

Figure 2 Intraoperative picture showing giant abdominal metastasis and both the ileal loops and left colon involved.

in a reference centre for sarcoma and he was deemed inoperable.

Because the symptomatology progressively worsened with continuous episodes of melena and severe anaemia, he showed up at our emergency department in extremely critical condition. Thoracoabdominal CT scan confirmed both abdominal and cardiac recurrences (figure 1). An emergency life-saving surgery was attempted. The giant mass of $30 \times 32 \times 35 \mathrm{~cm}$ was removed en bloc with $1 \mathrm{~m}$ of ileal loops and the descending colon (figure 2). Histopathological diagnosis was of highgrade dedifferentiated liposarcoma with MDM2 gene amplification. Previous histological specimens were reviewed, and it was concluded that this liposarcoma, although being more aggressive, had the same characteristics of the former two. The patient was discharged 17 days postoperatively in fair general conditions, but the cardiac relapse was judged unsuitable for surgery.

The patient was submitted to chemotherapy with trabectedin. His conditions remained stable for 1 year until the cardiac recurrence determined more and more frequent episodes of severe arrhythmia.

\section{Patient's perspective}

My husband was deemed inoperable in a sarcoma reference centre and we arrived at this emergency surgery unit in desperate conditions. Both my husband and I were convinced that there was nothing more to do. I would like to thank the surgeons who took the risk of operating on my husband in such conditions. It allowed us to live one more year together. I hope that my husband's case, dealing with what I understand is a very rare cancer, could serve as a lesson for surgeons. 


\section{Learning points}

- The heart should be taken into account as among the extremely rare localisations of liposarcoma. Abdominal metastases from cardiac liposarcoma are exceptional.

- In patients with both cardiac and abdominal localisation, it is difficult to establish its origin. The different timing of appearances could help to define the primary tumour, as in this case in which the cardiac localisation appeared 4 years before the abdominal one.

- Intestinal invagination could be one of the exceptional complications of the abdominal metastasis from cardiac liposarcoma. As far as we know, this is the second case reported in the literature.

- Surgery is the only effective treatment for patients with liposarcoma because chemotherapy and radiotherapy give poor results. An aggressive surgical treatment in a highvolume reference centre for sarcoma is significantly related to the overall survival. All major guideline statements endorse that all patients with sarcoma should be managed by a dedicated multidisciplinary team. The follow-up should be strict for the high risk of relapses. Instead, because our patient lived in a rural area, it was not as close as it should have been. So, the giant abdominal relapse was discovered too late and it made the surgical approach extremely complex.

- When deciding to operate on a patient with an exceedingly rare tumour like this, we can only rely on little information. It is remarkable how the prognosis of this patient was not as poor as anyone could have expected. A 14-month survival after surgery for giant metastatic abdominal recurrence should urge sarcoma reference centres to consider an aggressive approach also in patients in desperate conditions.

An abdominal CT scan revealed a small abdominal relapse, but this time, surgery was not performed for the cardiac condition. Death from cardiac arrest occurred 14 months after his last operation.

Liposarcoma is the second most common soft-tissue sarcoma. It occurs mostly in the limbs and retroperitoneum, while the heart is an extraordinary rare localisation. ${ }^{1-3}$ It is difficult to establish the origin of liposarcoma in this patient, but, since the cardiac tumour revealed itself 4 years before the abdominal one, it was speculated that the primary tumour was in the heart. Although cardiac metastasis of liposarcoma, though extremely rare, are well documented, ${ }^{2}$ abdominal metastases from cardiac liposarcoma are truly exceptional. ${ }^{3}$ To the best of our knowledge, this is a unique case of abdominal metastasis from cardiac liposarcoma with a very long survival: 7 years from the heart operation and 4 years from the metastasis' appearance. Moreover, this is the second case of an ileo-ileal invagination caused by bowel metastasis. ${ }^{3}$

Surgery is the only effective treatment for liposarcoma. A 14-month survival in a patient with both cardiac and abdominal recurrences should encourage surgeons to adopt an aggressive approach even in apparently untreatable cases.

Contributors VT and MC operated on the patient. VT and GG wrote the case report and acquired the clinical photographs. MGP made the histopathological investigations.

Funding The authors have not declared a specific grant for this research from any funding agency in the public, commercial or not-for-profit sectors.

Competing interests None declared.

Patient consent Next of kin consent obtained.

Provenance and peer review Not commissioned; externally peer reviewed.

Open access This is an open access article distributed in accordance with the Creative Commons Attribution Non Commercial (CC BY-NC 4.0) license, which permits others to distribute, remix, adapt, build upon this work non-commercially, and license their derivative works on different terms, provided the original work is properly cited, appropriate credit is given, any changes made indicated, and the use is non-commercial. See: http://creativecommons.org/licenses/by-nc/4.0/.

\section{REFERENCES}

1 He D, Chen M, Chen H, et al. Primary cardiac dedifferentiated liposarcoma with homologous and heterologous differentiation: a case report. Int J Clin Exp Pathol 2015;8:9662-6. eCollection 2015

2 Motevalli D, Tavangar SM. Extensive left ventricular, pulmonary artery, and pericardial metastasis from myxoid liposarcoma 16 years after the initial detection of the primary tumour: a case report and review of the literature. Malays J Pathol 2017:39:201-5.

3 Gomez G, Bilal M, Klepchick P, et al. Rare case of entero-enteric intussusception caused by small bowel metastasis from a cardiac liposarcoma. World J Gastrointest Oncol 2016:8:326-9.

Copyright 2018 BMJ Publishing Group. All rights reserved. For permission to reuse any of this content visit

http://group.bmj.com/group/rights-licensing/permissions.

BMJ Case Report Fellows may re-use this article for personal use and teaching without any further permission.

Become a Fellow of BMJ Case Reports today and you can:

- Submit as many cases as you like

- Enjoy fast sympathetic peer review and rapid publication of accepted articles

- Access all the published articles

- Re-use any of the published material for personal use and teaching without further permission

For information on Institutional Fellowships contact consortiasales@bmjgroup.com

Visit casereports.bmj.com for more articles like this and to become a Fellow 